\title{
ENTITAS METAFORA LEKSIKON FLORA MANDAILING TERHADAP KEBUDAYAANNYA
}

\author{
Putri Nasution \\ STIE Graba Kirana Medan
}

\begin{abstract}
Abstrak
Masyarakat Mandailing memiliki satu ragam bahasa yang dinamakan hata bulung-bulung (artinya bahasa daun-daunan). Berbeda dari bahasa yang biasa, kata - kata dalam hata bulung-bulung ialah daun tumbuh-tumbuhan yang dalam bahasa Mandailing disebut bulung-bulung. Daun-daunan yang digunakan ialah daun-daunan yang namanya mempunyai persamaan bunyi dengan kata-kata lainnya dalam bahasa Mandailing. Misalnya daun tumbuh-tumbuhan yang bernama sitarak digunakan untuk menyampaikan kata marsarak (berpisah). Daun tumbuhtumbuhan yang bernama pau (pakis) digunakan untuk menyampaikan kata diau (pada saya). Daun tumbuhan yang bernama sitanggis (setanggi) digunakan untuk menyampaikan perkataan tangis (menangis). Daun tumbuh-tumbuhan yang bernama podom-podom digunakan untuk menyampaikan perkataan modom (tidur). Daun tumbuh-tumbuhan yang bernama adungdung (madung) digunakan untuk menyampaikan perkataan dung (setelah). Daun tumbuhan yang bernama sitata (hita) digunakan untuk menyampaikan perkataan hita (kita). Dari ragam bahasa daunan atau flora itulah muncul bahasa Mandailing. Masyarakat Mandailing sendiri banyak yang tidak mengetahui tentang asal-usul bahasa Mandailing itu sendiri. Telah terjadi transformasi leksikon flora Mandailing yang membentuk satu makna dalam bahasa Mandailing itu sendiri yang mengandung nilai budaya yang sangat tinggi.
\end{abstract}

Keywords: bulung-bulung, flora, ekolinguistik, Mandailing

\begin{abstract}
The people of Mandailing have one language variety called hata bulung-bulung (meaning the language of the leaves). Different from common language, words in hata bulung-bulung are leaves called bulung-bulung in Mandailing language. Leaves that are used are those which names have similar sounds to other words in Mandailing. For example, sitarak leaves that is used for the word marsarak (meaning 'to separate'). Pau (fern) leaves is used for dian ('to me'). Sitanggis (setanggi) is used for tangis ('to cry'). Podom-podom leaves is used for modom ('to sleep'). Adungdung (madung) is used for dung ('after'). Sitata (bita) leaves is used for hita ('us/we'). From this leaves or flora language variety came Mandailing language. Many people of Mandailing themselves do not know the origin of their language. Mandailing's flora lexicon transformation had taken place that created a single meaning in Mandailing language that bear high cultural values.
\end{abstract}

Keywords: bulung-bulung, flora, ecolinguistics, Mandailing 


\section{Pendahuluan}

Lingkungan masyarakat bahasa dengan budayanya secara ekologis merupakan lingkungan buatan. Di dalamnya termasuk pula interaksi verbal antarpenutur dalam masyarakat yang memakai bahasa tersebut. Interaksi verbal ini merupakan kajian Sosiolinguistik. Sebagaimana dikatakan oleh Haugen (1972:25), lingkungan fisik suatu bahasa terdiri atas karakter geografi sebagai topografi suatu Negara dengan iklim dan intensitas curah hujan; dasar ekonomis kehidupan manusia yang terdiri atas fauna, flora, dan sumber-sumber mineral. Lingkungan sosial terdiri atas berbagai kekuatan masyarakat yang membentuk pikiran dan kehidupan setiap individu di antaranya: agama, etika, organisasi politik, dan seni. Berdasarkan klasifikasi pengaruh lingkungan diasumsikan ada faktor lingkungan yang tercermin dalam bahasa dengan anggapan sementara bahwa secara materi bahasa dipengaruhi lingkungan penuturnya.

Di sisi lain, bahasa yang hidup merupakan produk interaksi penuturnya dengan lingkungan, sebagaimana dinyatakan oleh Heine (1997:3) bahwa:

language structure is the product of our interaction with the world around us. The way we build discourses and develop linguistic categories can immediately be derived from the way we experience our environment and use that experience in species-specific communication.

Jelas bahwa struktur bahasa, demikian pula khazanah leksikon di dalamnya merupakan hasil interkasi manusia dengan dunia di sekitarnya, secara khusus dengan dunia flora di lingkungannya.

Hubungan yang interaktif antara lingkungan hutan di Kabupaten Mandailing dengan masyarakat Mandailing tercermin pada bahasa Mandailing, khususnya leksikon-leksikon yang menandai (encoding), tumbuh-tumbuhan yang ada di hutan-hutan itu. Penamaan dan pengodean adalah gambaran tentang interaksi, interelasi, bahkan interdependensi manusia dengan pelbagai tumbuhan khususnya. Kebertahanan leksikon yang mengodekan tumbuhan-tumbuhan di lingkungan hutan, disertai pula dengan tetap bertahan hidupnya tetumbuhan sebagai referensi kata atau leksikon tertanda, Jelas mengandung dan fungsinya bagi masyarakat pemilik leksikon dan tetumbuhan itu. Pengertian interdepensi juga berkaitan dengan keberadaan atau kehadiran secara harmoni dan berimbang, tanpa dominasi perlakuan manusia, khususnya yang kerap "menghabiskan" dan memusnahkan jenis tetumbuhan tertentu, sehingga, hilang pula leksikon-leksikon tertentu dalam bahasa tertentu.

Masyarakat bahasa Batak Mandailing berinteraksi dan bergantung pada lingkungan, khususnya lingkungan hutan yang ada di sekitar mereka; ketergantungan mereka dalam penggunaan jenis-jenis tetumbuhan selain untuk memenuhi kebutuhan material mereka, juga kebutuhan simbolik verbal yang bermakna cultural (totem, perlambangan, misalnya sirih pinang).

Mandailing merupakan salah satu etnik di Indonesia yang mendiami pedalaman pesisir pantai barat Pulau Sumatera. Sebagaimana dikatakan oleh Van Der Tuuk (1920) (dalam Lubis 1990 : 22), secara tradisional, Bahasa Mandailing terdiri atas lima ragam. Kelima ragam (dialek sosial) yang dimaksudkan itu adalah: (1) Hata Somal, ialah ragam bahasa yang digunakan dalam percakapan sehari-hari dan masih tetap hadir sampai pada masa sekarang, (2) Hata Andung, yaitu ragam bahasa sastra, yang pada masa dahulu khusus 
digunakan pada waktu meratapi jenasah dalam upacara kematian (disebut:mambulungi) dan juga ragam yang dipakai seorang gadis saat meratap di hadapan orangtuanya ketika akan berangkat meninggalkan mereka untuk selanjutnya dibawa ke rumah keluarga calon suaminya, (3) Hata Taes Dohot Jampolak, adalah ragam bahasa caci-maki yang khusus digunakan ketika terjadi hal-hal yang tidak baik (pertengkaran atau perkelahian), (4) Hata Sibaso, ialah ragam bahasa yang khusus digunakan oleh tokoh Sibaso (medium perantara alam nyata dan alam gaib) ketika berada dalam keadaan kesurupan. Ragam ini juga digunakan oleh Datu (penyembuh tradisional) pada waktu melakukan pengobatan, (5) Hata Parkapur, yaitu ragam bahasa sirkumlokasi yang dahulu digunakan oleh orang-orang Mandailing pencari kapur barus ketika berada di dalam hutan.

Di samping kelima macam ragam bahasa di atas, Van Der Tuuk (1920) (dalam Lubis, 1990:23) menyatakan juga bahwa pada masa lalu masyarakat Mandailing juga memiliki satu ragam bahasa lain yang dinamakan hata bulung-bulung (artinya bahasa daun-daunan). Berbeda dari bahasa yang biasa, kata - kata dalam hata bulung-bulung ialah daun tumbuhtumbuhan yang dalam bahasa Mandailing disebut bulung-bulung. Daun-daunan yang digunakan ialah daun-daunan yang namanya mempunyai persamaan bunyi dengan katakata lainnya dalam bahasa Mandailing. Misalnya daun tumbuh-tumbuhan yang bernama sitarak digunakan untuk menyampaikan kata marsarak (berpisah). Daun tumbuh-tumbuhan yang bernama pau (pakis) digunakan untuk menyampaikan kata diau (pada saya). Daun tumbuhan yang bernama sitanggis (setanggi) digunakan untuk menyampaikan perkataan tangis (menangis). Daun tumbuh-tumbuhan yang bernama podom-podom digunakan untuk menyampaikan perkataan modom (tidur). Daun tumbuh-tumbuhan yang bernama adungdung

(madung) digunakan untuk menyampaikan perkataan dung (setelah). Daun tumbuhan yang bernama sitata (hita) digunakan untuk menyampaikan perkataan hita (kita).

Bila daun hadungdung secara bersama-sama dengan daun sitata, daun sitarak, daun sitanggis dan daun podom-podom dikirimkan oleh seorang pemuda kepada kekasihnya, maka sang kekasih akan mengerti bahwa sang pemuda mengatakan kepadanya: "dung hita marsarak, jolo tangis au anso modom". Artinya, "setelah kita berpisah, menangis saya dahulu baru bisa tertidur".

Menurut pertuturan generasi tua pada masa lalu, bahasa daun-daun biasanya digunakan oleh muda-mudi (naposo na uli bulung) dalam masyarakat Mandailing, pada waktu mereka berpacaran. Pada masa lalu, dalam masyarakat Mandailing, orang yang berpacaran itu tidak dilakukan secara langsung dan terbuka. Oleh sebab itu, jika dua orang berpacaran hendak menyampaikan rasa cinta di antara mereka, mereka menggunakan bahasa daun-daunan. Jika seorang kekasih hendak menyampaikan daun-daunan sebagai "surat cinta" kepada pacarnya, dia harus melakukannya secara rahasia, misalnya, dengan meletakkan daun-daunan tersebut di satu tempat tertentu yang sudah mereka sepakati dan tidak diketahui orang lain. Secara sembunyi-sembunyi mereka yang berpacaran itu mengunjungi tempat rahasia tersebut secara bergiliran untuk melihat apakah tempat itu sudah ada surat cinta yang terdiri atas daun-daunan.

Seperti disinggung di atas bahwa kekayaan kata dalam bahasa Mandailing misalnya mencerminkan interkasi dan menunjukkan kekayaan pengetahuan masyarakat Mandailing tentang keberagaman lingkungan alam khususnya lingkungan flora dan fauna mereka. Berdasarkan pengetahuan tentang nama jenis atau spesies flora dan fauna dalam bahasa 
Mandailing itulah mereka menyimpan, memelihara, dan bahkan memenuhi kebutuhan hidup mereka secara material.

\subsection{Tujuan Khusus}

Tujuan khusus penelitian ini adalah :

1. Menganalisis dan mendeskripsikan perangkat kata apa saja dari leksikon Mandailing yang mengalami proses transformasi dari segi morfologi

2. Menganalisis dan mendeskripsikan makna metafora yang terkandung dalam leksikon flora Mandailing

3. Mendeskripsikan nilai makna kontekstual dalam leksikon flora Mandailing yang membangun nilai budaya pada masyarakat Mandailing

\subsection{Urgensi (Keutamaan) Penelitian}

Penelitian ini dibatasi pada ekoleksikal lingkungan (flora), karena cakupan ekolinguistik memang sangat luas. Dengan demikian tergambar pula aspek leksikografis ekologis tumbuhan (flora) sebagai gambaran kekayaan bahasa Mandailing. Dalam pembahasan kategorisasi perangkat leksikon yang mencakupi nomina, verba, dan adjektiva yang disertakan gambaran perubahan-perubahan yang ditandai dengan tidak dipakainya dan punahnya bahasa daundaunan (hata bulung-bulung) dalam masyarakat Mandailing. Selanjutnya ditampilkan pula ragam atau bentuk leksikon baru akibat pergeseran dan kepunahan.

Pada saat ini bahasa daun-daunan (hata bulung-bulung) dan penggunaannya sudah hilang dari tradisi budaya Mandailing. Hal ini diasumsikan karena punahnya tanamantanaman tersebut. Kepunahan tanaman tersebut berarti kepunahan leksikon-leksikon yang sangat merugikan kelompok etnis Mandailing, termasuk bangsa Indonesia. Tanaman tersebut merupakan kekayaan budaya Indonesia di lingkungan yang telah mengalami perubahan, sesuatu yang sudah punah sangat sulit untuk dihidupkan kembali.

\subsection{Kerangka Teori}

Perubahan bahasa menyangkut soal bahasa sebagai kode. Sesuai dengan sifat bahasa yang dinamis, dan sebagai akibat persentuhan dengan kode-kode dari bahasa lain, bahasa itu selalu berubah. Pergeseran bahasa menyangkut masalah mobilitas penutur sebagai akibat dari perpindahan penutur, atau disebabkan penutur yang tadinya menggunakan bahasa ibu kemudian menjadi tidak menggunakannya lagi. Adapun pemertahanan bahasa lebih menyangkut masalah sikap atau penilaian terhadap suatu bahasa, untuk tetap menggunakan bahasa tersebut ditengah-tengah bahasa-bahasa lainnya.

\subsection{Teori Ekolinguistik}

Ekolinguistik sebagai paradigma kelinguistikan yang relatif baru layak untuk dikembangkan. Istilah ini pertama kali dikenalkan Haugen (1972: 14) dalam tulisannya yang bertajuk Echology of Language. Ekolinguistik dipilih karena cakupannya yang luas. Pakar bahasa dapat bekerjasama dengan sejumlah bidang ilmu sosial lainnya dalam membedakan kompleksitas bentuk dan makna bahasa dalam kualitasnya dengan lingkungan alam pada umumnya dan lingkungan manusia pada khususnya. 
Ekologi bahasa ini (Haugen,1972: 14-15) merupakan lingkungan kebahasaan, bagian dari lingkungan alam, dan merupakan lingkungan "buatan" manusia dan masyarakat. Di lingkungan manusia itu pasti hadir, hidup, dan terjadi saling interaksi, saling memengaruhi antara bahasa-bahasa tersebut dalam kehidupan kejiwaan, kebudayaan, dan kemasyarakatan mereka. Selain itu, setiap bahasa, melalui penuturnya, berinteraksi dengan lingkungan alam di sekitarnya. Interaksi antara bahasa yang satu dengan bahasa yang lainnya, saling memengaruhi terjadi melalui mental, sikap, dan perilaku dalam berinteraksi dan berkomunikasi secara verbal. Dalam kondisi kebahasaan yang dwibahasaan (bilingualism), atau anekabahasaan (multingualism), saling pengaruh, saling menyerap unsur-unsur kebahasaan sering terjadi, baik secara luas maupun secara mendalam. Dalam konteks ini, bahasa yang lebih kuat, yang berposisi superstruktur, mendominasi bahasa-bahasa yang berposisi sebagai substratum (Band. Jeffers dan lehiste,1979:13). Bahasa yang lebih kuat, pada kenyataannya memang lebih mendominasi dan menghegemoni bahasa yang lebih lemah.

Konsep ekologi bahasa menurut Haugen berkaitan dengan pengertian bahwa language ecology may be defined as the study of interactions between any given language and its

environment (Haugen dalam Peter, 1996:57). Ekologi bahasa dapat didefenisikan juga sebagai studi tentang interaksi antarbahasa yang ada dengan lingkungannya.

Ecology is the study of plants and animals, as individuals and together in populations and biological communities, in relations to either environments the physical, chemical, and biological characteristics of their surroundings.(1976:1)

Ekologi merupakan studi yang mempelajari tumbuh-tumbuhan dan hewan-hewan sebagai individu dan secara bersamaan dalam populasi dan komunitas biologis dalam kaitannya dengan lingkungan fisik, kimia dan karakteristik biologis lingkungannya.

Ekolinguistik adalah suatu disiplin ilmu yang mengkaji hubungan antarlingkungan dan bahasa juga tentang bahasa lingkungan. Ekolinguistik merupakan ilmu bahasa interdisipliner, menyanding ekologi dan linguistik (Mbete, 2009:1). Berdasarkan hal itu bahasa sangat berkaitan erat dengan lingkungannya sendiri. Bahasa tersebut bisa bertahan, bergeser, hilang atau musnah apabila ekologi yang menunjangnya tetap hadir atau musnah pula.

Penelitian ini bertujuan untuk memberi gambaran atas pengertian tentang Ekolinguistik itu sendiri.

Masyarakat adat atau masyarakat tradisional adalah suku-suku dan bangsa yang mempunyai kelanjutan historis dengan msyarakat sebelum masuknya pandangan yang menganggap dirinya berbeda dari kelompok masyarakat lain yang hidup di wilayahnya. Oleh sebab itu terdapat hubungan yang nyata terkait pelbagai perubahan ekologis terhadap bahasa. Lebih luas lagi, perubahan-perubahan ekologis tersebut turut memengaruhi nilai, ideologi dan budaya sebagai bagian dari identitas keetnikan masyarakat.

Haugen (1970, lihat Mbete 2009:11-12) menyatakan bahwa ekolinguistik memiliki kaitan dengan sepuluh ruang kaji, yaitu :1. linguistik historis komparatif; 2. linguistik demografi; 3. sosiolinguistik; 4. dialinguistik; 5 . dialektologi; 6. filologi; 7. linguistik preskriptif; 8. glotopolitik; 9. etnolinguistik, linguistik antropologi ataupun linguistik kultural (cultural linguistics); 10. tipologi bahasa-bahasa di suatu lingkungan. Berdasarkan pembagian Haugen tersebut, penelitian ini terkait dengan ruang kaji sosiolinguistik dan linguistik perspektif termasuk leksikografi di dalamnya (leksikografi). 
Dalam lingkup kajian ekolinguistik, bahasa yang hidup dan digunakan menggambarkan, mewakili, melukiskan (mempresentasikan secara simbolik-verbal) realitas lingkungan, baik lingkungan fisik maupun lingkungan buatan manusia (lingkungan sosial-budaya). Sementara itu, perubahan pada bahasa tampak jelas pada tataran leksikon. Alasannya kelengkapan leksikon dari suatu bahasa mencerminkan sebagian besar karakter lingkungan fisik dan karakteristik sosial serta budaya masyarakat penuturnya.

Kajian interdisipliner yang diprakarsai oleh Haugen selanjutnya diajukan pula konsep ekologi dan linguistik dengan menerapkan konsep dasar berupa parameter ekologi bersatu dengan kajian ekolinguistik, seperti yang dijelaskan oleh Fill dan Munlhausler (2001:1). Parameter ekologi, sekaligus juga parameternya ekolinguistik adalah: 1. keterhubungan (interrelationship), 2. lingkungan (environment), 3. keberagaman (diversity), digunakan seperti kepada analisis wacana lingkungan, pragmatik, antropolinguistik, semantik kognitif, dan lainnya.

Perubahan pada bahasa terdapat juga pada tataran leksikon. Leksikon pada bahasa Mandailing mencerminkan karakter lingkungan fisik dan karakteristik sosial dan budaya pada masyarakat Mandailing. Seperti yang diajukan oleh Sapir dalam Fill dan Muhlhausler (2001:14) sebagai berikut :

"It is the vocabulary of a language that most clearly reflects the physical and social environment of its speakers. The complete vocabulary of a language may indeed be looked upon as a complex inventory of all the ideas, interest, and occupations that take up the attention of the community, and were such a complete thesaurus of the language of a given tribe at our disposal, we might to a large extent infer the character of the physical environment and the characteristics of the culture of the people making use of it. It is not difficult to find examples of languages whose vocabulary thus bears the stamp of the physical environment in which the speakers are palced"

Sapir (dalam Fill dan Muhlhausler, 2001:2) menambahkan bahwa dalam lingkup ekolinguistik, hubungan bahasa dan lingkungannya ada pada tataran leksikon saja, bukan pada tataran fonologi atau morfologi (this interrelation exists merely on the level of the vocabulary and not, for example, on that of phonology or morphology).

\section{Metodologi}

\subsection{Lokasi Penelitian}

Penelitian ekolinguistik kepunahan bahasa flora Mandailing ini dilakukan pada empat Kecamatan yaitu pertama, di Kecamatan Panyabungan, fokus penelitian di Desa Gunung Tua Jae dan Gunung Tua Julu. Kedua, Kecamatan Siabu, fokus penelitian di Desa Sihepeng dan Siabu. Ketiga, Kecamatan Muara Sipongi, fokus penelitian di Desa Kampung Pinang dan Huta Baringin. Keempat, Kecamatan Muara Batang Gadis di Desa Hutarimbaru dan Sikapas. Keempat kecamatan tersebut merupakan daerah yang masih banyak flora-flora yang sangat erat hubungannya dengan masyarakat Mandailing. Masyarakat Mandailing masih banyak bergantung hidupnya pada flora-flora yang ada di daerah mereka tinggal. Misalnya masih banyak yang memanfaatkan flora pau, sitarak dan lain-lain. Di Kecamatan tersebut masih banyak dijumpai informan-informan yang banyak mengetahui tentang keberadaan flora-flora Mandailing 


\subsection{Sumber Data dan Data Penelitian}

Sumber data yang utama dalam penelitian ini adalah kata-kata yang berhubungan dengan flora dan selebihnya adalah data tambahan seperti dokumen dan lain-lain. Data penelitian ini bersumber dari data lisan dan data tertulis tentang leksikon flora bahasa Mandailing. Jumlah data dikumpulkan, tidak tergantung pada jumlah tertentu, melainkan pada taraf di mana dirasakan telah memadai.

Sumber data primer penelitian ini adalah para penutur yang dijadikan sebagai nara sumber data utama juga. Subjek nyata atau individu nyata sebagai nara sumber dipercayai memiliki kompetensi untuk menceritakan pengalamannya, secara khusus pengalaman kebahasaan berdimensi pada sosiekologis. Disisi itu, metode kualitatif bersandar pada ungkapan makna verbal subjektif yang diberikan individu yang diteliti. Sesuai dengan konteks sosioekologis dalam penelitian ini, fungsi terpenting ungkapan-ungkapan itu ibarat jendela untuk melihat kehidupan bathin dan kahzanah pengetahuan, pengalaman kebahasaan, kebudayaan, dan lingkungan hidup para penutur bahasa yang diteliti (lihat Denzin dan Lincoln, 2009:15).

\subsection{Metode dan Pengumpulan Data}

Sementara itu, teknik yang digunakan dalam penelitian ini adalah teknik wawancara berstruktur. Dalam wawancara berstruktur itu semua pertanyaan telah dirumuskan semuanya

dengan cermat, dengan cara menyuruh subjek penelitian ini bercerita tentang floraflora yang ada di Kecamatan Siabu, Muara Sipongi, Muara Batang Gadis, khususnya pada daun sitarak, pau, sitanggis, podom-podom, hadungdung, sitata. Penelitian juga dibantu dengan teknik:

\section{a. Observasi}

Observasi naturalistik/alamiah (naturalistic observation) terhadap situasi dan pandangan sosial adalah salah satu teknik pengumpulan data sosial. Metode observasi alamiah adalah langkah awal bagi observasi partisipan yang lebih luas. Menurut kaum post-postivistik, problem observasi sangat banyak, termasuk masalah validitas dan reliabilitas, bias peneliti dan konteks sosial, pengaruh peneliti dan kealpaan cek keanggotaan. Keduanya mendiskusikan strategi-strategi tradisional-multimetode untuk membahas seperti isu-isu, yang sekaligus menunjukkan bagaimana metode tersebut dikukuhkan penerapannya secara baik oleh kaum sosiologi-formal. Patricia Adler dan Peter Adler (1985:24) menjelaskan problem-problem etis yang terkandung dalam metode observasi adalah masalah etis seputar pelanggaran privasi. Mereka mencatat bahwa agenda-agenda tersembunyi adalah salah satu identitas yang biasa dipakai oleh para peneliti ilmu pengetahuan sosial.

\section{b. Wawancara (Interview)}

Data leksikon flora diperoleh dari dokumen tertulis, observasi nonpartisipan, dan wawancara berstruktur. Wawancara terstruktur dan terbuka dilakukan dengan beberapa orang informan. Observasi nonpartisipasi dilakukan terhadap situasi 
disekitar daerah kecamatan Panyabungan, Siabu, Muara Sipongi, Muara Batang Gadis, misalnya mengamati tumbuh-tumbuhan yang terdapat disekitar daerah tersebut dan berbagai kegiatan, perilaku, dan tindakan penutur bahasa Mandailing, sebagaimana dijelaskan Basrowi dan Suwandi (2008:94),"......observasi tidak terbatas pada orang tetapi juga objek-objek alam lainnya."

\section{c. Metode-Metode Visual}

Para pakar sosiologi dan antropologi visual biasanya menggunakan film, video dan fotografi sebagai alat untuk mencatat dan mendokumentasi kehidupan sosial. Dalam penelitian hanya menggunakan fotografi sebab fotografi mampu membawa seorang peneliti langsung ke dunia nyata, yang isu-isu tentang identitas peneliti, sudut pandang subjek peneliti, dan apa yang dibawa seni fotografi menjadi problem tersendiri. (Douglas Harper 1981: 26). Metode visual menempati posisi penting dan urgen dalam penelitian kualitatif. Pendokumentasian sebagai sebuah teks sosial merupakan strategi dan sumber penting. Bidang ini akan menjadi metode terdepan untuk membaca, mengonstruksi, dan menafsirkan berbagai teks sosial.

\subsection{Teknik Analisis Data}

Analisis data dalam penelitian ini dilakukan sejak sebelum memasuki lapangan, selama di lapangan, dan setelah selesai di lapangan. Dalam hal ini Nasution (2003) menyatakan analisis data kualitatif telah dimulai sejak merumuskan dan menjelaskan masalah, sebelum terjun ke lapangan, dan berlangsung terus sampai penulisan hasil penelitian. Analisis data menjadi pegangan bagi penelitian selanjutnya. Dalam penelitian ini, analisis data lebih dimulai dari pengumpulan data dari dokumen yang tersedia, dan dilanjutkan pengumpulan data dari lapangan, yaitu hasil wawancara dari informan. Setelah itu, data tersebut dianalisis dan dikategorisasi perangkat leksikon yang mencakupi nomina, verba, dan adjektiva yang disertakan gambaran perubahan-perubahan yang ditandai dengan tidak dipakainya dan punahnya bahasa daun-daunan (hata bulung-bulung) dalam masyarakat Mandailing.

\section{Hasil dan Pembahasan}

Van Ophuysen dalam Harahap (2004:155) mengungkapkan bahwa orang Mandailing adalah salah satu suku bangsa yang memiliki bahasa daun. Oleh sebab itu peneliti berpendapat bahwa bahasa daun ini harus diangkat sebagai salah satu khazanah kebudayaan orang Mandailing dan harus diteliti lebih dalam lagi. Keberadaan bahasa daun menunjukkan bahwa betapa sensitif dan dekatnya masyarakat Mandailing dengan alam. Masyarakat Mandailing mempunyai filosofi yang mendasari sikap dan perilaku mereka dalam bergaul dengan alam sehingga mereka tercapai ekologi alam dan manusia yang seimbang.

Dapat diketahui bahwa jati diri orang Mandailing terdapat dalam bahasa daun. Daundaunan yang namanya mirip atau sama dengan lafal kata yang dipakai dalam percakapan sehari-hari. Ada beberapa dedaunan yang sudah dikenal luas oleh orang Mandailing. Pilihan daun sebagai kosa kata bahasa daun terutama didasarkan pada persamaan atau kemiripan lafal nama daun dengan kata-kata dalam kosa kata bahasa Mandailing. Sebagian dari daundaun itu adalah tumbuhan obat yang biasa dipakai oleh datu sebagai pulungan ni ubat, 
sebagai ramuan obat.

Berikut ini adalah nama daun-daunan dan makna konteks penggunaan atau pesan yang ingin disampaikan:

Tabel 1.

\begin{tabular}{|l|l|l|l|l|}
\hline No & Nama daun & $\begin{array}{l}\text { Bahasa } \\
\text { Mandail- } \\
\text { ing }\end{array}$ & $\begin{array}{l}\text { Bahasa Indo- } \\
\text { nesia }\end{array}$ & $\begin{array}{l}\text { Makna/Pesan yang Disampai- } \\
\text { kan }\end{array}$ \\
\hline 1. & Adungdung & Dung & Sudah & $\begin{array}{l}\text { Digunakan untuk menyampaikan } \\
\text { kata } \text { madung atau sudah }\end{array}$ \\
\hline 2. & Galunggung & Tinggang & $\begin{array}{l}\text { Tindih/ting- } \\
\text { gang }\end{array}$ & $\begin{array}{l}\text { Digunakan untuk menyampaikan } \\
\text { kata tinggang atau tindih }\end{array}$ \\
\hline 3. & Hasior & Sior mata & $\begin{array}{l}\text { Tajam/pengli- } \\
\text { hatan }\end{array}$ & $\begin{array}{l}\text { Digunakan untuk menyampaikan } \\
\text { kata } \text { modom atau tidur }\end{array}$ \\
\hline 4. & Podompodom & Modom & Tidur & $\begin{array}{l}\text { Digunakan untuk menyampaikan } \\
\text { kata } \text { modom atau badan, tubuh }\end{array}$ \\
\hline 5 & Pau & Au & Aku & $\begin{array}{l}\text { Digunakan untuk menyatakan } \\
\text { kata } \text { au atau aku }\end{array}$ \\
\hline 6. & Pandan & Padan & Janji/ikrar & $\begin{array}{l}\text { Digunakan untuk menyampaikan } \\
\text { kata togu atau janji/ikrar }\end{array}$ \\
\hline 7. & Sitarak & Marsarak & Berpisah & $\begin{array}{l}\text { Digunakan untuk menyampaikan } \\
\text { kata } \text { marsarak atau berpisah }\end{array}$ \\
\hline 8. & Sitata & Hita & Kita & $\begin{array}{l}\text { Digunakan untuk menyampaikan } \\
\text { kata } \text { hita } \text { atau kita }\end{array}$ \\
\hline 9. & Sitanggis & Tangis & Menangis & $\begin{array}{l}\text { Digunakan untuk menyampaikan } \\
\text { kata tangis atau menangis }\end{array}$ \\
\hline 10. & Tanaon & Tonahon & Pesankan & $\begin{array}{l}\text { Digunakan untuk menyampaikan } \\
\text { kata tonahon atau pesankan }\end{array}$ \\
\hline 11. & Uban-uban & Uban & Uban & $\begin{array}{l}\text { Digunakan untuk menyampaikan } \\
\text { kata } \text { } \text { uban } \text { atau uban }\end{array}$ \\
\hline
\end{tabular}

Metafora adalah ungkapan kebahasaan untuk mengatakan sesuatu yang hidup bagi mahluk hidup lainnya, yang hidup untuk yang mati, yang mati untuk yang hidup, atau yang untuk yang mati (ILevin 1977:79). Metafora merupakan pemahaman dan pengalaman akan sejenis hal yang dimaksudkan untuk perihal yang lain. Dilihat dari segi sintaksis, metafora dapat dibagi menjadi tiga kelompok yaitu, (1) metaforik nominatif, (2) metafora nominatif, metafora predikatif dan (3) metafora kalimat.

Pada metafora nominatif lambang kiasnya hamya terdapat pada nomina kalimat. Karena posisi nomina itu dalam kalimat yang berbeda-beda, metaforanominatif dapat pula dibagi menjadi dua macam yaitu (1) metafora nominatif subjektif dan metafora objektif, atau lazim disebut juga sebagai metafora nominative komplementatif. Pada metafora nominatif subjektif, lambang kias muncul hanya pada subjek kalimat, sementara komponenkomponen kalimat yang mengandung metafora tetap dinyatakan dengan kata-kata yang mempunyai makna langsung

Metafora nominatif objektif atau metafora nominatif komplementatif memakai lambang kias hanya pada objek atau komplemen kalimat yang dimaksud, sedangkan komplemen lain dalam kalimat tetap dinyatakan dengan kata yang mempunyai makna 
langsung.

Metafora predikatif, kata-kata lambang kias hanya terdapat pada predikatif kalimat, sedangkan subjek dan komplemen kalimat (jika ada) masih dinyatakan dalam makna langsung.

Jenis metafora terakhir, yang dipandang dari segi sintaksis ialah metafora kalimat. Seluruh lambang kias yang dipakai dalam metafora ini tidak terbatas pada nominatif (baik subjek maupun objek) dan predikatnya saja, melainkan seluruh komponen dalam kalimat metaforis itu merupakan lambang kias.

Contoh kalimat-kalimat yang dibentuk dari bahasa daun dengan menggunakan nama daunan beserta maknanya:

Kalimat Taringot tu padanta i, godang situtu do rohangku "Mengenai janji kita itu, aku berbesar hati". Daun yang digunakan dalam kalimat diatas adalah daun pandan, yang terdapat pada data no 45. Bunyinya sama dengan kata padanta dalam bahasa Mandailing yang arti dari kata padanta tersebut adalah janji atau ikrar. Kalimat diatas memiliki makna metafora. Sementara, jenis metafora yang terlihat dari kalimat tersebut adalah metafora nominatif objektif atau metafora nominatif komplementif. Kata-kata godang situtu do rohangku, 'aku berbesar hati'berfungsi sebagai komplemen kalimat Taringot tu padanta i....' mengenai janji kita.......' . godang situtu do rohangku, 'aku berbesar hati' adalah katakata kias yang makna sebenarnya adalah menerima semua yang telah disepakati dan senang akan janji tersebut.

Kalimat Pabolkas jolo tonangku tu si......"Tolong sampaikan pesan saya kepada si... ..Daun yang digunakan dalam kalimat diatas adalah daun tanaon yang terdapat pada data no 82. Bunyinya sama dengan kata tonahan dalam bahasa Mandailing yang arti dari kata tonahan tersebut yaitu pesankan. Kalimat tersebut memiliki makna langsung kepada seseorang, tidak ada makna kias kalimat tersebut. Jadi tidak ada makna metafora.

Kalimat Jaru jabat pe bontar uban kujujung laing ko do lungunku "Biarpun kepalaku sudah beruban, engkau tetap ku rindukan". Daun yang digunakan dalam kalimat diatas adalah daun uban-uban yang terdapat pada data no 90 dan daun galunggung yang terdapat pada data no 22. Daun uban-uban bunyinya sama dengan kata uban dalam bahasa Mandailing yang artinya adalah uban. Sedangkan daun galunggungung bunyinya sama dengan kata malungun dalam bahasa Mandailing yang arti dari kata malungun tersebut yaitu rindu atau kangen. Kalimat diatas memiliki makna metafora. Jenis metafora yang terlihat dalam kalimat tersebut adalah metafora predikatif. Kata sudah beruban, merupakan predikatif subjek kalimat biarpun kepala ku. Dalam metafora tersebut, sudah beruban (ungkapan kebahasaan dengan makna langsung) dihayati untuk menyatakan sudah tua atau sudah diatas empat puluh tahun.

Kalimat Dung hita na marsarak i, laing na jolo tangis do au anso modom "Sejak kita berpisah itu, aku selalu menangis barulah tidur". Daun yang digunakan dalam kalimat diatas adalah daun sitarak yang terdapat pada data no 74 . Daun adungdung yang terdapat pada data no 1 ,daun sitanggis yang terdapat pada data no 73 , daun podom-podom yang terdapat pada data no 53 dan daun pau yang terdapat pada data no 49. Daun sitarak bunyinya sama dengan kata marsarak dalam bahasa Mandailing yang arti dari kata marsarak tersebut yaitu berpisah. Daun adungdung bunyinya sama dengan kata madung dalam bahasa Mandailing yang arti dari kata madung tersebut yaitu sudah. Daun sitarak bunyinya sama dengan kata hita dalam bahasa Mandailing yang arti dari kata hita tersebut adalah kita. Daun sitanggis 
bunyinya sama dengan kata tangis dalam bahasa Mandailing yang arti dari kata tangis tersbut yaitu menangis. Daun podom-podom bunyinya sama dengan kata modom dalam bahasa Mandailing yang arti dari kata modom tersebut adalah tidur. Sedangkan daun $p a$ bunyinya sama dengan kata au dalam bahasa Mandailing yang arti dari kata au tersebut yaitu aku. Jenis metafora di atas adalah metafora kalimat. Seluruh kalimat diatas memiliki makna kias. Tidak ada satu komponen pun di dalam kalimat itu yang mempunyai makna langsung. Metafora kalimat di atas mengandung makna "perpisahan itu membuat hati sangat sedih dan pilu, sehingga tidak bisa tidur, kalau pun bisa tidur harus menangis terlebih dahulu.

Kalimat Mardomu tu dalan ma hita, muda dapot eme on "Kita bertemu di jalan, setelah panen padi". Daun yang digunakan dalam kalimat yaitu daun sitopu yang terdapat pada data no 76 dan daun sitomu dalan yang terdapat pada data no 75. Daun sitopu memiliki persamaan bunyi dengan kata mardomu dalam bahasa Mandailing yang artinya adalah bersatu atau bergabung. Sedangkan, daun sitomu dalan memiliki persamaan bunyi dengan kata mardomu tu dalan dalam bahasa Ma dailing yang artinya yaitu bertemu di jalan. Kalimat tersebut memiliki makna langsung kepada seseorang, tidak ada makna kias kalimat tersebut. Jadi tidak ada makna metafora.

Kalimat Muda ditatap ko au, sior matamu tu halak. "Jika engkau menatap aku, tajamkan matamu kepada orang lain". Daun yang digunakan dalam kalimat yaitu daun pau, daun hasior yang terdapat pada data no 33. Daun pau memiliki persamaan bunyi dengan kata au dalam bahasa Mandailing yang artinya aku. Sedangkan daun hasior memiliki persamaan bunyi dengan kata sior mata yang artinya adalah tajam penglihatan. Jenis metafora di atas adalah metafora nominatif objektif. Pada metafora di atas, kata-kata sior matamu tu halak "tajamkan matamu ke orang lain" berfungsi sebagai komplemen kalimat muda ditatap ko au jika engkau menatap aku" adalah kata-kata kias yang makna sebenarnya adalah tidak sanggup menatap mata mu itu.

Kebudayaan bergantung pada ruang dan waktu, oleh sebab itu kebudayaan senantiasa mengalami perubahan. Perubahan budaya adalah proses adaptasi sesuai dengan keadaan lingkungan hidup manusia. Adaptasi kebudayaan dipengaruhi oleh berbagai hal (Basyral Hamidy, 2004:355), 1) kontaknya dengan kebudayaan lain pada masa lampau dan masa kini, 2) sejarah tradisi, 3) cara hidup dan cara-cara mengantisipasi gejala alam semesta, 4) tanggapan terhadap perubahan masyarakat yang pesat. Dalam hal ini, manusia menentukan sikap, cita-cita dan nilai-nila sesuai dengan kebutuhannya dalam lingkungan tertentu dan pada waktu tertentu pula.

Dalam proses adaptasi tersebut akan tercipta nilai-nilai budaya, yaitu konsep-konsep mengenai apa yang dianggap bernilai, berharga, luhur dan mulai. Sehingga semuanya dapat dijadikan pedoman yang memberi arah dan orientasi kepada kehidupan masyarakat. Mulai proses sosialisasi, setiap anggota masyarakat diresapi dengan nilai-nilai budaya yang hidup di dalam masyarakat. Sehingga konsep-konsep itu berakar secara mendalam di dalam jiwanya.

Dapat diambil kesimpulan bahwa nilai budaya masyarakat Mandailing berkaitan dengan adanya pandangan hidup masyarakat Mandailing yang bergantung kepada alam (terbentuknya bahasa Mandailing dari bahasa daun-daunan) sehingga tercipta hakikat hubungan denga alam dan hakikat hubungan antar manusia.

Bagi masyarakat Mandailing, alam bukanlah sesuatu yang harus ditakuti. Alam 
adalah bagian dari kehidupan mereka, bahkan dipandang sebagai sumber kesejahteraan hidup. Mereka hidup dari dan dengan alam. Pergaulan hidup dengan alam membuat suasana harmonis antara mereka dan alam sekitarnya. Setelah berinteraksi dengan alam maka terjalin pula hubungan antar manusia. Antara masyarakat yang ada disekitar mereka.

Hubungan antar manusia sangat kuat terjalin dalam sistem kekerabatan Dalihan Natolu (DNT), Setiap orang, setiap kelompok kerabat, memiliki hak dan kewajiban seimbang. Hubungan kekerabatan bukan saja diimplemntasikan di dalam sesame kelompok masyarakat Mandailing. Hubungan ini diperkuat dengan ajaran agama Islam yang mereka anut. Salah satu syarat kehidupan yang berbahagia di dunia dan akhiratadalah hubungan vertical dengan Maha Pencipta, Allah SWT, dan hubungan horizontal sesame manusia sebagai sesame mahluk. Nilai-nilai hubungan antar manusia yang kuat itu dengan sendirinya menjadi bagian dari jati dirinya.

Semangat kekitaan menurut orang Mandailing merupakan syarat untuk mencapai hidup yang harmonis. Kata hita dan ta sebagai pernyataan milik, merupakan bukti dari tingginya rasa milik dan penghargaan orang Mandailing terhadap orang lain, misalnya inangta, amangta, ompungta, namborunta, angginta, tulangta, dan seterusnya. Bahkan orang Mandailing terbiasa menyebut hak miliknya dengan memakai kata tambahan ta sebagai pernyataan kepemilikan bersama, misalnya bagasta (rumah kita) bukan bagasku (rumahku).

Hubungan antar manusia seperti itu terus terpelihara melalui pengalaman semangat kekerabatn yang kuat dalam tradisi martarombo atau mencari hubungan kekerabatan melalui silsilah. Tradisi ini bukan hanya berlaku terhadap sesame orang Mandailing. Karena hubungan primordial dapat dibina juga dengan orang asing melalui jaringan hubungan dengan tokoh yang mereka kenal. Nilai - nilai kerukunan dan kebersamaan yang luhur itu telah mulai mengalami erosi. Erosi itu antara lain timbul dari pengaruh perubahan yang drastic dalam hubungan antar manusia yang lebih mengutamakan prhitungan rugi laba. Akibatnya kehangatan hubungan antar manusia menjadi berkurang. Jika hubungan itu dirasakan membawa kerugian, khususnya secara material akan terjadi hubungan yang dingin.

Perubahan persepsi terhadap perubahan hubungan antar manusi itu merupakan perubahan terhadap hubungan antar manusia dalam bingkai DNT. Hubungan manusia dalam bingkai DNT adalah hubungan resiprokal yang dilandasi oleh rasa holong, kasih saying. Jika rasa holong melemah, maka hubungan manusia antar anggota kerabat dengan sendirinya melemah juga. Salah satu yang dapat melemahkan rasa holong itu adalah kuatnya kepentingan pribadi yang bernuansa material. Hubungan ekonomi lama kelamaan memasuki hubungan kekerabatan, sehingga sangat potensial menimbulkan konflik kepentingan. Dalam keadaan demikian pertolongan sering dianggap tidak bermuatan rasa holong karena pertolongan tidak jarang bernuansa pamrih. Sering pula terjadi bahwa, bantuan atau pertolongan seringkali dipandang oleh orang yang ditolong sebagai sesuatu kewajiban si penolong untuk memberikan pertolongan. Sampai pada tingkat ini, telah terjadi erosi yang kuat terhadap rasa terima kasih. Hal demikian dapat menimbulkan kejeraan. Hal ini tidak terlepas dari meningkatnya kepentingan pribadi dan persaingan yang semakin kuat.

Setengah abad yang lalu orang yang memiliki pohon durian dan pohon langsat biasa memberikan kesempata kepada kerabat-kerabatnya untuk mendapat giliran sehari semalam 
menunggu durian jatuh atau memtik langsat untuk dimakan sendiri. Keadaan ini tidak terjdi lagi sekarang, karena ketika pohon itu mulai berubah, sudah ada orang yang bersedia membeli durian dan langsat yang masih muda itu. Sistem ijon ini telah ikut merenggangkan hubungan kekerabatan yang pada gilirannya mengurangi kebiasaan berterima kasih.

Dari sudut lain, hubungan kekrabatan yang diambil alih oleh hubungan perorangan atas dasar jual beli itu, bermuatan semangat emansiporis. Semangat untuk mengubah nasib itu berlangsung ditengah-tengah dinamika dan persaingan yang semakin keras. Semangat emansiporis itu berkaitan dengan upaya perbaikan mutu kehidupan masa kini dan masa depan. Perbaikan mutu kehidupan masa depan itu hampir tak berhenti bagi pembiayaan pendidikan anak-anak.

\section{Simpulan}

Leksikon Mandailing memiliki jenis dan makna metafora yaitu; 1) Metafora nominatif objektif atau metafora nominative komplementif. Contoh kalimatnya; taringot tu padanta $i$, godang situtu do rohangku 'aku berbesar hati' berfungsi sebagai komplemen kalimat 'taringot tu padanta i .....'mengenai janji kita.....', godang situtu do rohangku, 'aku berbesar hati' adalah kata-kata kias yang makna sebenarnya adalah menerima semua yang telah disepekati dan senang akan janji tersebut, 2) metafora predikatif. Contoh kalimatnya; jaru jabat pe bontar uban kujujung laing ko do lungunku 'biarpun kepalaku sudah beruban, merupakan predikatif subjek kalimat 'biarpun kepala ku'. Dalam metafora, sudah beruban menyatakan sudah tua. 3) metafora kalimat. Contoh kalimatnya, dunghita na marsarak $i$, laing na jolo tangis do au anso modom 'sejak kita berpisah itu, aku selalu menangis barulah tidur'. Seluruh kalimat di atas memiliki makna kias. Tidak ada satu komponen pun di dalam kalimat itu yang mempunyai makna langsung.

Konteks makna dalam leksikon flora Mandailing membangun nilai budaya pada masyarakat Mandailing. Hubungan antara manusia sangat kuat terjalin dalam system kekerabatan Dalihan Natolu (DNT). Setiap orang, setiap kelompok kerabat, memiliki hak dan kewajiban seimbang. Semangat kekitaan menurut orang Mandailing merupakan syarat untuk mencapai hidup yang harmonis. Kata hita dan ta sebagai pernyataan milik, merupakan bukti dari tinggimya rasa milik dan penghargaan orang Mandailing terhadap orang lain, misalnya inangta, amangta, ompungta, namborunta, angginta, tulangta dan seterusnya. Bahkan orang Mandailing terbiasa menyebut hak miliknya dengan memakai kata tambahan ta sebagai pernyataan kepemilikan bersama, misalnya bagasta (rumah kita) bukan bagasku (rumahku). 


\section{DAFTAR PUSTAKA}

Adler, P. 1985. Wheeling and Dealing. New York: Columbia University Press.

Bagus, I Gusti Ngurah, Aron Meko Mbete, Ni Luh Sutjiati Bratha 1995-1999.

Kedwibahasaan di Bali dan Nusa Tenggara Dibiayai Dana URGE B a t c h IV. Proyek Tinggi Departemen Pendidikan dan Kebudayaan.

Baker, Mona. 1992. In Other Words: A Coursebook on Translation. London: Routledge.

Bellwood, Peter. 2000. Prasejarah Kepulauan Indo-Malaysia. Jakarta: Gramedia Pustaka Utama.

Booij, Geert. 2007. The Grammar of Words: An Introsduction to Linguistic Morphology. Great Britain: Oxford University.

Bundasgaard, Jeppe \& Sune Steffensen 2000 'The Dialetics of Ecological Morphology or the Morphology of Dialectics dalam Ana Vibeke Lindo \& Jeppe Bundasgaard (eds) 2000 Dialectical Ecolinguistics. Odense : University of Odense.

Chaer, Abdul. 2006. Tata Bahasa Praktis Bahasa Indonesia. Edisi Revisi. Jakarta:Rineka Cipta.

Corbin, Juliet. 2003. Dasar-Dasar Penelitian Kualitatif. Tata Langkah dan TeknikTeknik Teoritis Data. Yogyakarta: Pustaka Pelajar.

Crystal, David. 2000. Language Death. UK: Camridge University.

Denzin, Norman K, Yvonna S. Lincolon (Eds) 2009. Handbook of Qualitative Research. Terjemahan Daryanto dkk. Yogyakarta: Pustaka Pelajar.

Fill, Alwin dan Peter Mühlhäuser. 2001. The Echolinguistics Reader Language, Ecology And Environment. London : Continuum.

Fitri, Isnen, dkk.2000. inventori Arsitektur Tradisional Mandailing Godang. Medan: Program Studi Arsitektur Fakultas Teknik. Universitas Sumatera Utara.

Fromkin, Victoria dan Robert Rodman. 1974. An Introduction to Language. New York : Holt Rinehart and Winston Inc.

Gladston. 1987. Language and Culture. London: Longman.

Harimurti, Kridalaksana. 1982. Kamus Linguistik. Jakarta: Penerbit. Gramedia Pustaka Utama.

Haugen, Einer. 1972. The Ecology of Language. Standford, CA: Standford University Press.

Holmes, Janet. 2001. Introduction to Sociolinguistics. (Ed.Kedua). Harlow, Essex: Longmann.

Jeffers, Robert J and Ilse Lehiste. 1979. Principles and Methods for Historical Linguistics. Cambridge: The MIT Press.

Landini dan Conely. 2009. "Metode Pengalaman Pribadi" dalam Norman K. Denzin, Yvonna S. Lincoln (Eds). 2009. Handbook of Qualitative Research. Edisi bahasa Indonesia: Yogyakarta: Pustaka Pelajar.

Lindo, Ann Vibeke dan Jeppe Bundsgaard (eds). 2000. Dialectical Ecolinguistics Three Essays for the Symposium 30 Years of Language And Eccology in Graz December 2000. Odense: University of Odense.

Lyons, John. 1968. Introduction to Theoretical Linguistics. London, New York: Cambridge University Press

Lubis, Pangaduan. 1990. "Sastra Mandailing dan Kita: Suatu Perkenalan Awal. Seawaktu "Diskusi Kebudayaan Mandailing" di Fakultas Sastra Awal. Seawaktu "Diskusi Kebudayaan Mandailing" di Fakultas Sastra Universitas 
Sumatera Utara.

Mahsun. 2005. Metode Penelitian Bahasa: tahapan strategi, metode, dan Ttekniknya.Ed. Revisi. Jakarta : RajaGrafindo Persada.

Mbete, Aron Meko. "Ekologi Bahasa". Bahan Matrikulasi Program Magister Linguistik PPs Universitas Udayana.

Mbete, Aron Meko. 2010. "Sekilas Tentang Linguistik Kebudayaan". Bahan Sederhana untuk Berbagi Pengalaman dengan Mahasiswa Program Studi Magister Linguistik Program Pascasarjana Universitas Diponegoro, Semarang, 7 Mei 2010.

Mbete, Aron Meko. 2009. "Selayang Pandang Tentang Ekolinguistik: Perspektif Kelinguistikan Yang Prospektif." Bahasa Untuk Berbagi Pengalaman Kelinguistikan Dalam Matrikulasi Program Magister Linguistik Program Pascasarjana Universitas Udayana, 12 Agustus 2009.

Mbete, Aron Meko. 2009. "Problematika Keetnikan dan Kebahasaan dalam Persfektif Ekolinguistik.'Disampaikan dalam Seminar Nasional Budaya Etnik III, Diselenggarakan oleh USU, Medan April 2009.

Mbete, Aron Meko dan Abdurrahman Adisaputera. 2009. Penyusutan Fungsi Sosioekologis Bahasa Melayu Langkat pada Komunitas Remaja di Stabat, Langkat.

Mbete, Aron Meko.2002. "Ungkapan-Ungkapan dalam Bahasa dan Fungsinya Dalam Melestarikan Lingkungan". Linguistika. Vol. 9:No. 17. Program Studi Magister dan Doktor Linguistik Universitas Udayana, September 2002. 174-186 .

Mbete, Aron Meko. 2001. "Beberapa Perubahan Makna dalam Bahasa Lio, Flores. "Linguistika. Tahun VIII, Edisi 15. Program Studi Magister dan Doktor Linguistik Universitas Udayana, September 2001. 79-86.

McMahon, April M.S. 1999. Understanding Language Change. Cambridge: Cambridge University Press.

Moleong, J. Lexy. 2004. Metode Penelitian Kualitatif. Bandung: PT. Remaja. Rosdakarya.

Miles, Mattew B dan A. Michael Huberman, 2007. Analisis Data Kualitatif. Penerjemah: Tjetjep Rohendi Rohidi. Jakarta: Universitas Indonesia. Mufwene, Salikoko S .2004. The Ecology of Language Evolution. Cambrdige: Cambridge University Press.

Odum, Eugene P. 1996. Dasar-dasar Ekologi. Edisi ketiga. Penerjemah: Tjahjono Samingan. Yogyakarta: Gadjah Mada University Press.

Palmer, F.R. 1976. Semantics a New Outline. Cambridge University.

Pateda, Mansoer. 2001. Semantik Leksikal. Jakarta: Rineka Cipta.

Patilima, Hamid. 2005. Metode Penelitian Kualitatif. Bandung: Alfabeta.

Rahardi, R. Kunjana. 2006. Dimensi-Dimensi Kebahasaan. Aneka Masalah Bahasa Indonesia Terkini. Jakarta: Erlangga

Sudaryanto. 1993. Metode dan Aneka Teknik Analisis Bahasa. Yogyakarta: Duta Wacana.

Suparwa, I Nyoman. Ekologi Bahasa dan Pengaruhnya dalam Dinamika KehidupanBahasa Melayu Loloan Bali. Fakultas Sastra Universitas Udayana.

Verheijen, Jilis A.J. 1984. "Plant Names in Austronesian Linguistics. "Nusa, LinguisticStudies of Indonesian and Other Languages in Indonesia, 20.

Wardhaugh.R.1972. Introduction to Sosiolinguistics. Oxford: Basil Blackwell Ltd 